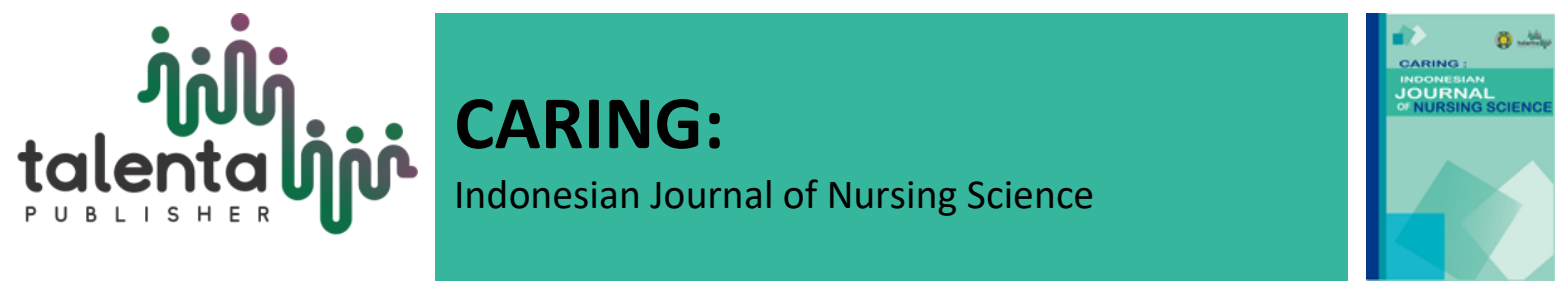

\title{
Analysis of Imbalance Between Government Regulations and Nursing Education on Industrial Nurses
}

\author{
Syaifoel Hardy ${ }^{1}$, Asep Hermawan Sanudin ${ }^{2}$, Ridha Afzal ${ }^{3}$, Isak JH Tukayo ${ }^{4}$ \\ ${ }^{I}$ Indonesian Nursing Trainers, Indonesia \\ ${ }^{2}$ Department of Healthcare, Qatar Petroleum, Qatar \\ ${ }^{3}$ Indonesian Nursing Trainers, Indonesia \\ ${ }^{4}$ Poltekkes Kemenkes Jayapura, Indonesia
}

\begin{abstract}
In Indonesia, industrial nurses are only required to have an Occupational Safety and Health (K3) certificate up to this time. This policy is not in line with Law No. 36/2014. As a result, there is an imbalance between industry needs for quality nursing services and existing nurses' competence. This study aimed to analyze policies related to the competencies of corporate nurses in meeting the needs of health care services in the industry. This study used PRISMA Flow Diagram as a systematic review supported by quantitative descriptive design. The research was conducted through document searches, identifying keywords, and reviewing articles from Google Scholar (6 records), Research Gate (8 records), and PubMed (5 records), and others were 52 records. Out of 71 documents, 36 records were assessed for eligibility, and 35 records were excluded, and 16 studies were included in the review. It was found that there was an imbalance between the regulations, education programs, and implementation. It requires the strengthening of a multisectoral approach in the development of $\mathrm{OH}$ nursing education.
\end{abstract}

Keyword: OHN; nursing; policy; occupational safety and health

Received $14^{\text {th }}$ April $2021 \mid$ Revised $21^{\text {th }}$ May 2021 $\mid$ Accepted $18^{\text {th }}$ June 2021

*Corresponding author at: Jl. A.Yani, Komp. Griya Husada A2/9, Lawang, Jawa Timur, Indonesia

E-mail address: saderun@gmail.com 


\section{Introduction}

In Indonesia, the main requirement for nurses working in the industry up to this time is only a certificate of Occupational Safety and Health (K3) (Ministry of Manpower, 1979). This policy is not in line with Law No. 36 of 2014 concerning Health Personnel and Regulation of the Minister of Health of the Republic of Indonesia Number 26 of 2019 concerning Implementation Regulations of Law Number 38 of 2014 concerning Nursing. This policy creates an imbalance between the demands for health services quality in the industry and existing nurses' availability. As of 2017, there were 26.71 million companies (Andreas, 2017). 3.9 million of which were new companies (Agustinus, 2017). Based on data per April 26, 2020, it states that the Government has issued operational permits and mobility for industrial activities to 14,533 companies. These companies come from agro-industry, chemical, pharmaceutical and textile, metal industry, machinery, tools and electronics, small, medium and various industries, as well as industrial estates and industrial services (CNBC, 2020). The industrial sector has a total workforce of 4,330,215 people (CNBC, 2020). These companies need health services for the welfare of their employees. However, the increased industrial growth in various sectors in Indonesia has not been matched by the availability of competent industrial nurses produced by nursing education institutions (Tukayo \& Hardy, 2020). Competent nurses are nurses who have core abilities required to fulfill one's role as a nurse (Fukada, 2018).

According to $\mathrm{WHO}$, the role of $\mathrm{OHN}$ nurses in the industry includes clinicians, nursing managers, mentors, educators, researchers, and coordinators (WHO, 2001). In order to have this role, formal education and legal recognition are needed. These two conditions are needed in order to be called professional (Nehril et al., 2016). The unavailability of OHN specialist education occurs because the number of specialist nursing education is only eight specializations (Efendi et al., 2018). In addition, the number of nurses who have industrial competence in Indonesia is based on having K3 certification (Tukayo \& Hardy, 2020). The minimal number of industrial nurses is indicated by the limited number of OHN training institutions (BPPSDM, 2018) and the scarcity of scientific works on OHN (Tukayo \& Hardy, 2020). Even though the industry continues to develop and requires the latest health services, including nurses who work in the industrial sector (BPS, 2020). So far, OHN courses have been integrated into Community Health Nursing in the nursing undergraduate education program. The absence of this OHN educational institution in the future will hinder not only the career path of the nursing profession but also the quality and quantity of OHN services in the industrial world. This article attempts to review Government policies or regulations of Ministerial Regulations, which are not in line with the Law on Healthcare Workers and the Nursing Law. 


\section{Research Method}

This study used PRISMA Flow Diagram as a systematic review supported by quantitative descriptive design. The research was conducted through document searches, identifying keywords, and reviewing articles from Google Scholar, Research Gate, and PubMed. The authors used the descriptive method because the data and information collected focus on actual phenomena and problems in the form of the roles and competencies of nurses in the industry through data collection, compilation, processing, and concluding (Rizki \& Nawangwulan, 2018). The results were used to describe an objective empirical state of the phenomenon or problem being studied. The data collection technique used was a literature study. The authors applied this because of various limitations in interviewing directly with authoritative sources (Notoatmodjo, 2018). The results were obtained by following the Preferred Reporting Items for Systematic Reviews and Meta-Analysis (PRISMA) Flow Diagram in which the data were divided into three steps: identification (records identified from database and records removed), screening (records screened and records excluded; records sought for retrieval and not retrieved; assessed for eligibility and records excluded) and included (studies included in the review).

\section{Research Results}

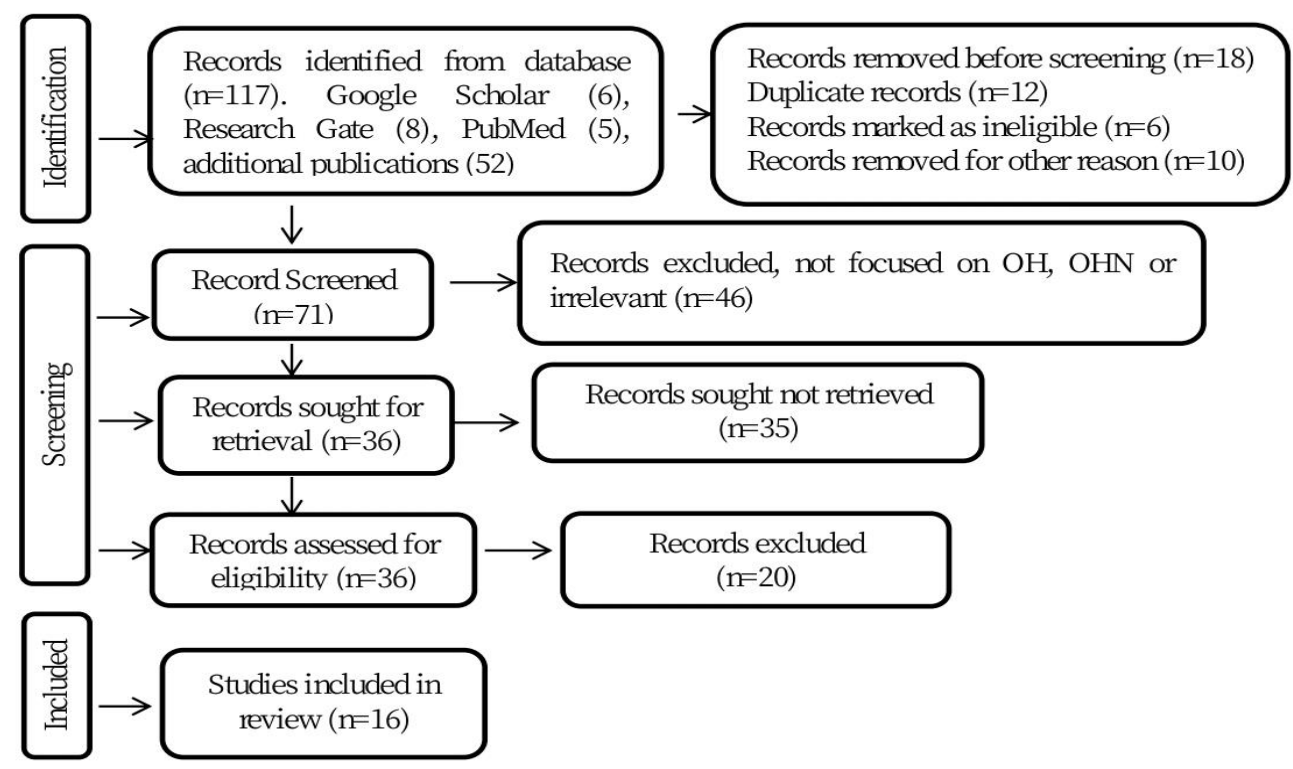

Diagram 1. Result Analysis Based on PRISMA Flow Diagram

The diagram above shows that initially, 117 records were identified from the database, of which 71 records were screened and 46 records excluded. Records sought for retrieval, assessed for eligibility, and studies included in the review were 36 records. A similar method was used by $\mathrm{Al}$ Johani and Pasqua (AAOHN, 2015) in the field of Occupational Health to show the number of identified publications and the eligibility. 
The table and pictures below are the main records found in the search focus on this study. They are the OHN Competencies by the American Association of OHN (WHO, 2016). These two documents are internationally recognized as the requirement of $\mathrm{OHN}$ education and $\mathrm{OH}$ nurses in the workplace. They can be used as recommendation besides the international standards recommended by WHO (Kono et al., 2018).

Table 1. OHN Competencies

\begin{tabular}{|c|}
\hline $\begin{array}{l}\text { Competencies } \\
\text { sendently and with other team me }\end{array}$ \\
\hline Manages Total Worker Health independently and with other team members \\
\hline $\begin{array}{l}\text { supports clients' } \\
\text { nniques }\end{array}$ \\
\hline $\begin{array}{l}\text { - Uses data to identify trends and control health and safety risks, and to inform and implement } \\
\text { policy decisions at the department, organizational, and systems levels }\end{array}$ \\
\hline -Identifies hazards and exposures and recommends effective controls for their mitigation \\
\hline $\begin{array}{l}\text { and evaluates programs and services designed to improve health and safety } \\
\mathrm{s}\end{array}$ \\
\hline $\begin{array}{l}\text { - Coordinates client care to effectively promote health, manage illness and injury, prevent } \\
\text { disability, and facilitate return to work }\end{array}$ \\
\hline Adheres to principles of professional nursing Practice \\
\hline $\begin{array}{l}\text { - Practices nursing ethically, competently, and within the legal scope of practice, ensuring } \\
\text { compliance with all requirements of local, state, and federal laws; obtains and maintains } \\
\text { necessary licenses and certifications required to practice }\end{array}$ \\
\hline ence and lifelong learning throughout career \\
\hline lth and safety \\
\hline es to develop evidence-based \\
\hline and federal laws, ensuring confidentiality and \\
\hline 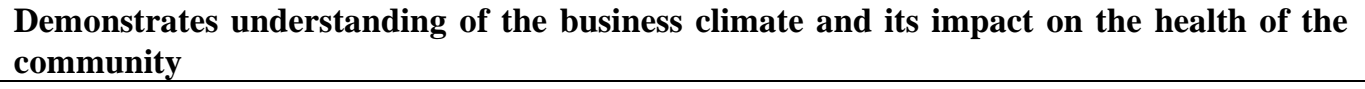 \\
\hline $\begin{array}{l}\text { ent knowledge of and compliance with applicable laws and regulations that } \\
\text { ctice, workers, workplaces, and the environment }\end{array}$ \\
\hline $\begin{array}{l}\text { Advises employers of regulations that may affect occupational and environmental health } \\
\text { operations }\end{array}$ \\
\hline $\begin{array}{l}\text { es for ethical decision-making in regard to worker, business, and community concerns } \\
\text { ts }\end{array}$ \\
\hline he broad impact of economics on a target population's health and well-being \\
\hline $\begin{array}{l}\text { Gathers an occupational and environmental health history, conducts assessment and applies } \\
\text { knowledge of work processes and hazards/ exposures for accurate clinical decision-making, } \\
\text { including placement, and return-to-work decisions }\end{array}$ \\
\hline od steward of budget dollars allotted and practices within budgetary constraints \\
\hline $\begin{array}{l}\text { Communicates the direct and indirect consequences of injury and illness on worker } \\
\text { productivity, employee engagement, and quality of life }\end{array}$ \\
\hline $\begin{array}{l}\text { Participates on and/or leads interdisciplinary teams, including those that plan for and respond to } \\
\text { emergencies, pandemics, and disasters }\end{array}$ \\
\hline $\begin{array}{l}\text { Practices culturally-appropriate, evidence-based nursing care within licensed scope of } \\
\text { practice }\end{array}$ \\
\hline
\end{tabular}

Educates, counsels, and coaches clients on identifying, reducing, and eliminating health and safety risks

Collaborates with workers, management, the community, and other professionals to meet the health and safety needs of clients

Analyzes and evaluates clinical service delivery using evidence-based strategies for continuous quality improvement.

Source: AAOHN, 2015. 
The table above shows four competency areas that OHN nurses must have-namely having the principle of independent work, working according to professional practice, understanding business and its impact on community health, and applying evidence-based practice according to the scope of nursing license.

Table 2. OHN Core Competencies Summary in the Workplace

\section{Occupational Health Nursing Core Competencies Summary}

The nurse below has demonstrated professional nursing competencies in the comprehensive assessment, planning, implementation and evaluation of care for all age groups to include:

- Accurately documents and codes patient encounter

- Appropriately delegates authority, accountability, and duties for Occupational Health Nursing care.

- Assists with developing policies and procedures and standards of care for all patients. Fosters interdisciplinary collaborative relationships among other services to ensure provision of quality care. Prioritizes tasks and manages time schedules, personnel, and resources to meet unit department goals and patient care standards.

- Applies knowledge of various diseases and effectively communicates preventive measures. Uses different methods of education to assist the comprehension of the client Coordinates services for the individual to achieve health goals.

- Determines the state of health of the worker by performing assessments, examinations, and monitoring of the worker via pre-placement and periodic certification/surveillance examinations.

- Conducts workplace visits to identify potential hazards harmful to the workers' health with regards to the work environment, production processes, and equipment handling practices.

- Ensures program compliance with Federal Mandated Laws and Programs.

- Develops and implements management strategies to provide input into the mission of the command.

- Takes responsibility and accountability for professional development as an Occupational and Environmental Health Nurse.

- Develops strategies for programs to increase employee's awareness of workplace hazards, the effect of the hazards on their health and protective equipment to be used to protect the employee from the hazards.

- Discusses the meaning and application of results from health risk appraisals; promotes positive lifestyle interventions such as smoking cessation and improved exercise and nutrition; designs strategies to help alter attitudes and behaviors to improve health; and encourages self-responsibility for utilization of health resources.

- Recognizes key symptomology of combat operational stress, PTSD, and traumatic brain injury. Identifies need for referral/evaluation of stress reduction, psychoeducation, and behavioral health interventions for the prevention of and reduction of operational stress disorders for patient or family

- Recognizes key components of the military and operational unique situations such as Pre and Post Deployment, Preventive Health Assessment for individual readiness.
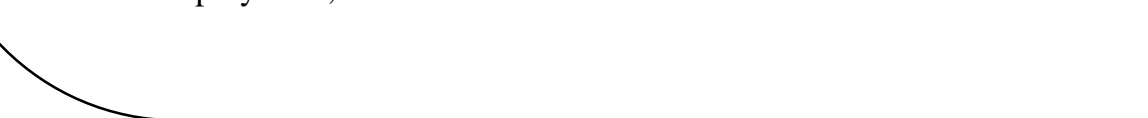

Source: www.med.navy.mil

The table above shows the competencies that OHN nurses practically must have in the workplace, which, if summarized, includes comprehensive assessment, planning, implementation, and evaluation of care for age groups. Both lists of competencies above are United States of America (USA) OHN-based competencies which are internationally used as 
references by $\mathrm{OHN}$ departments of many universities, colleges of nursing, and nursing practice industries (Kono et al., 2018).

\section{a. Government Policy}

In Chapter X, Article 86 of Law No.13 of 2003 concerning Manpower; every worker has the right to work safety and health protection. The Safety and Occupational Health Protection stated in this document is clarified by seven documents of ministerial regulations reviewed in this article (Three from the Ministry of Manpower, four from the Ministry of Health) (UndangUndang RI, 2003). These documents contain policies regarding the requirements for health workers in the industry, including nurses who are referred to as paramedics in ministerial regulations. The terms 'nurse' and 'nursing' are discussed in two documents (Law No. 36 and No. 38/2014). The two types of documents are in the form of Ministerial Regulations obliging the existence of health services in the industry through providing occupational safety and health (K3) of health professionals. In the Minister of Manpower's regulation, nurses are referred to as Paramedics, whereas in the Nursing and Health Workers Act, nurses are a separate profession, not paramedics.

\section{b. Industrial Nurses Requirements}

Indonesian Ministry of Health Regulation No.52/2018 requires OSH services in every health service facility. This regulation also requires OSH training as described in Article 9. Nurses who work in companies known as Paramedics in the document must attend $\mathrm{K} 3$ training $(\mathrm{MoH}$, 2018). According to clinical guidelines at work ( $\mathrm{MoH}, 2009)$, there are three job requirements: 1. Initial level, namely nurses who take short-term training on K3. 2. Basic Level: nurses who have received short K3 training. Level III (international standard): K3 services led by an expert, led by K3 doctors, and Level IV: comprehensive services carried out by K3 nurses. K3 training is organized by the Ministry of Manpower (BPPSDM, 2018). K3 nurses are specialist nursing personnel with specialist educational backgrounds (HSE Prime, 2021). According to WHO Specialist Occupational Health, a Nurse is a fully trained Registered Nurse, in addition to their general nursing education and training at the University-degree level.

\section{c. OH Nurses Training and Competency Module}

General K3 Training Teaching Materials Module in Indonesia contains 6 modules with the composition: Occupational Safety and Health Characteristics, Occupational Safety and Health in General, Occupational Safety and Health in Laboratories, Hospitals and Occupational Safety and Health in Industry (BPPSDM, 2018). The modules given to nurses contain theory, practicum and company visits including occupational health legislation, occupational safety and health basics, physical hazards, biology, chemistry, psychology and ergonomics, occupational diseases, SMK3 and K3 management systems, Industrial Sanitation, Occupational Health 
Reporting, Occupational Nutrition and Work Productivity, Industrial Toxicology, Industrial Hygiene, including Social Security Program Waste Management (HSE Prime, 2021). This training module is delivered for 4-5 training days. Meanwhile, the OHN Education Module varies according to the level of education, from the Bachelor Degree to the Doctoral Degree in OHN (McCullagh, 2012). The OHN nurse is prepared for various specialist positions. Specialist education prepares nurses to practice as coordinators, health promotion specialists, managers, and consultants. Some programs prepare additional roles, such as nurse practitioner, researcher, and educator (AAOHN, 2004). From 889 existing nursing education campuses in Indonesia (Efendi et al., 2018), the K3 education program is still customary with a general module (Ratnawati, 2018).

\section{Research Discussion}

Three things need to be corrected from all existing documents: the absence of synchronization between the use of the term nurse as a paramedic, the gap between the competence of paramedics and nurses as stated in the laws and regulations as well as the existing education system. The first is about synchronizing the use of the term 'Paramedic.' In the Regulation of the Minister of Manpower and Transmigration No: PER.01/MEN/1979, Article 1 states: Every company that employs medical personnel must send each of these personnel to receive training in corporate hygiene, occupational health, and safety fields. The term Paramedic for Nurse is not correct as it is also stated in the Minister of Manpower Regulation. Moreover, Paramedics in Indonesia do not yet have educational institutions (Efendi et al., 2018). According to the Nursing Law, nurses are legally recognized and have individual levels of education and produce professionals who are recognized in higher education standards in Indonesia (MoH, 2019).

Law No.36 concerning Health Workers explains that what is meant by Health Workers as referred to in Article 8 letter (a) must have a minimum qualification of Diploma Three, except medical personnel. Nurses in the law are not paramedics. Paramedics have their educational background, which in Indonesia does not yet exist. For example, in the United States, Paramedics have curricula, length of education, and levels and degrees different from nursing. Paramedics in the United States have their education level. So paramedics are not nurses as written in the Manpower Act and the Ministry of Manpower Regulation. Paramedics are not included in the Health Workforce Law as a profession as nurses (MoH, 2014b). Second, regarding the requirements for health workers in the industry, it is mentioned that they have Hiperkes training. In the Regulation of the Ministry of Manpower, it is stated in Article 2 that what is meant by health workers are Paramedics. In Law No.36 concerning Health Workers, there is no health worker named Paramedics. Thus the definition of paramedics needs to be clarified because nurses are not paramedics (Tukayo \& Hardy, 2020). Therefore, these regulations need to be reviewed. Third, the purpose of providing health services in companies is to provide protection and care for workers to health and safety in the workplace where it is 
necessary to guarantee its implementation. Thus, workers can truly relish it. In order to achieve this goal, it is necessary to prepare professional staff as stipulated in the Health Manpower Law No.36 of 2014. Healthcare workers referred to in this law must at least take a diploma education. With only the title of Hiperkes training, it cannot be called a professional health worker in their field, according to the Healthcare Manpower Law No.38 (MoH, 2014a). The socalled professionals are competent, pursue higher education, have a code of ethics, and are legally recognized (Fukada, 2018). The level of nursing education in Indonesia is clear on the type, level and degree (MoH, 2019). Likewise, as what is meant by the nursing profession (HSE Prime, 2021).

The placement of health workers according to their qualifications and specializations in industrial health, in this case, nursing, is a step that is in line with the objectives of health policies contained in the National Health System (Tumurang, 2019). Industrial nursing services have been carried out by developed countries (Rogers et al., 2009), even in Malaysia (Malaysia Department of OSH, 2005). This is necessary for healthcare services steps in order to be able to measure the performance indicators in industrial sectors (IPIECA, 2019).

Providing an OHN specialist education program will support the welfare of the company's employees, boost and improve the professionalism of nurses, and improve the quality of OHN services in the industry. All this time, formal education programs at the undergraduate and postgraduate level specialist occupational safety and health (K3) are still organized by the Faculty of Public Health at many large campuses (University of Indonesia, Gajah Mada University, Diponegoro University, Airlangga University, Hasanudin University) (Tukayo \& Hardy, 2020). This condition can be a challenge as well as an opportunity. Although there is recognition of the certification program in the form of $\mathrm{K} 3$ training, however, the $\mathrm{OHN}$ Specialist program will make it easier for nurses who want to study OHN according to their career path recognized as formal education $(\mathrm{MoH}, 2014 \mathrm{a})$. The policies related to the requirements for nurses working in the industry thus need to be re-evaluated. From sharing references, the above research shows the increasing demands for accreditation and certification in various healthcare services, including in industry, requiring the support of healthcare workers with formal educational backgrounds to improve the quality and quantity of $\mathrm{OH}$ services in the industry.

\section{Conclusion}

The purpose of carrying out occupational safety and health activities, in general, is to create a safe and healthy environment or atmosphere in the workplace to prevent work accidents concerning employee maintenance so that employee loyalty to the company is well maintained. To achieve this goal, it is necessary to support established regulations from the Government in 
developing healthcare-related education, including OHN. However, in the process of its journey, along with the development of the industrial world, demands for the quality and quantity of occupational health services and personnel, the development of occupational health nursing education, as part of the global trends, government rules, and other regulations, need to adapt to all these changes.

\section{REFERENCES}

[1] Andreas, D. (2017). Indonesia Kini Punya 26,71 Juta Perusahaan. Online. Available at https://tirto.id/indonesia-kini-punya-2671-juta-perusahaan-cnz4.Accessed on 25 March 2021.

[2] Agustinus, M., (2017). Ada 3,98 Juta Perusahaan Baru di RI dalam 10 Tahun Terakhir. Online. Available at: https://finance.detik.com/berita-ekonomi-bisnis/d3485474/ada-398-juta-perusahaan-baru-di-ri-dalam-10-tahun-terakhir. Accessed on 25 March 2021.

[3] CNBC. (2020). 14 Ribu Pabrik Beroperasi, 4,3 Juta Pekerja Bekerja di Tengah Corona.Online.Available at https://www.cnbcindonesia.com/news/202004281436404-154980/14-ribu-pabrik-operasi-43-juta-buruh-kerja-di-tengah-corona. Accessed on 21 Februari 2021.

[4] Tukayo, I. JH \& Hardy. S. (2020). Manajemen Perawatan Kesehatan Kerja: Panduan Keperawatan di Industri untuk Mahasiswa Perawat, Akademisi dan Praktisi. Perawatan Kesehatan Kerja. Malang: CV Ismaya Berkah Group. Pp. 17-37.

[5] Fukada, M. (2018). Nursing Competency: Definition, Structure and Development. Yonago Acta Medica. Yonago, Japan, 1-7.

[7] Nehril, Batool, Vanaki, Z., Nouri, JM., Khademolhosseini, SM., Ebadi, A., (2016). Competency in Nursing Students: A Systematic Review, International Journal of Travel Medicine and Global Health. Iran. 2016, 3-11.

[8] Efendi, F., Chen, CM, Kurniati, A., Nursalam, Yusuf, MA. (2018). Situation Analysis of Nursing Education and Workforce in Indonesia. Malaysian Nursing Journal. Vol. Arpil 9 (4), 20-29.

[9] BPPSDM. (2018). Modul Materi Ajar K3. Kementerian Kesehatan RI. Jakarta.

[10] BPS. (2020). Direktori Industri Manufaktur. Online. Available at: https://www.bps.go.id/publication/2020/10/29/0ccce4731b6f3ad5e457fd99/direktoriindustri-manufaktur-2020.html. 2020, Accessed on 25 March 2021.

[11] Rizki, M.R., \& Nawangwulan, S. (2018). Metodologi Penelitian Kesehatan, Populasi dan Sampel. Sidoarjo: Indomedia Pustaka, 83-94.

[12] Notoatmodjo, Soekidjo. (2018). Metodologi Penelitian Kesehatan. Metode Penelitian Survei, Jakarta: Rineka Cipta, 37-41.

[13] Al Johani, Wael Abdullah and Pascua, Glezzeelyne Pascual. (2019). Impacts of Manual Handling Training and Lifting Devices on Risks of Back Pain among Nurses: An Integrative Literature Review, Nurse Media Journal of Nursing, 9(2), 210-230.

[14] AAOHN. (2015). Workplace Health \& Safety, AAOHN Competencies, November 2015, 484-492.

[15] Navy Medicine, Occupational Health Nursing Core Competencies Individual Assessment, 1-13.

[16] WHO. (2016). Nurse Educator Core Competencies, WHO Library Cataloguing-inPublication Data, Pp.4-36, 2016, WHO Document Production Services, Geneva, Switzerland.

[17] Kono, Keiko; Goto, Yuki; Hatanaka, Junko; Yoshikawa, Etsuko. (2018). Competencies Required for Occupational Health Nurses, International Journal of Africa Nursing Sciences, 105-110. 
[18] Kemenkes RI, Permenkes No.52/2018 tentang Keselamatan dan Kesehatan Kerja di Fasyankes, Jakarta. 1-7.

[19] Departemen Kesehatan RI, Pedoman Klinik Perusahaan, Jakarta, 1-31.

[20] HSEPrime.com. (2021). Pelatihan Ahli K3 Umum. Online. Available at: https://www.hseprime.com/pelatihan-ahli-k3-umum/. 2021, Accessed on 25 March 2021.

[21] McCullagh, MC. (2012). Occupational Health Nursing Education for the 21st Century, Workplace Health \& Safety, Vol. 60, No. 4, 167-176.

[22] AAOHN, Standards of Occupational and Environmental Health Nursing, USA., 004, 1-12.

[23] Kemenkes RI. (2019). Profil Kesehatan Indonesia 2019, Jakarta, Kementerian Kesehatan, 49-73.

[24] Kemenkes (Ministry of Health). (2014). Undang-Undang RI no. 36 Tahun 2014 Tentang Tenaga Kesehatan. Kementrian Kesehatan RI, Jakarta. 2014b, 1-28.

[25] Tumurang, MN. (2019). Kebijakan Kesehatan Nasional, Sistem Kesehatan Nasional, Sidoarjo.

[26] IPIECA. (2019). Health Performance Indicator: A Guide for the Oil and Gas Industries, Accessed on 12 Desember 2019 di http://www.ipieca.org/sites/default/files/publications/HPI.pdf. 2019.

[27] Ratnawati. (2018). Modul Hiperkes. Unpub. Conference Proceedings. 1- 47.

[28] Kemenkes (Ministry of Health). (2014). Undang-Undang RI No.38 Tahun 2014 Tentang Keperawatan. Kemenkes RI, Jakarta.1-52. 